Abstracta Iranica

Revue bibliographique pour le domaine irano-aryen

Volume 34-35-36 | 2017

Comptes rendus des publications de 2011-2013

\title{
M. Cool Root. Elam in the Imperial Imagination: From Nineveh to Persepolis
}

\section{Astrid Nunn}

\section{(2) OpenEdition}

1 Journals

\section{Édition électronique}

URL : http://journals.openedition.org/abstractairanica/41432

DOI : 10.4000/abstractairanica.41432

ISSN : 1961-960X

Éditeur :

CNRS (UMR 7528 Mondes iraniens et indiens), Éditions de l'IFRI

\section{Référence électronique}

Astrid Nunn, « M. Cool Root. Elam in the Imperial Imagination: From Nineveh to Persepolis », Abstracta Iranica [En ligne], Volume 34-35-36 | 2017, document 6, mis en ligne le 15 juillet 2016, consulté le 02 octobre 2020. URL : http://journals.openedition.org/abstractairanica/41432 ; DOI : https://doi.org/ 10.4000/abstractairanica.41432

Ce document a été généré automatiquement le 2 octobre 2020.

Tous droits réservés 


\title{
M. Cool Root. Elam in the Imperial Imagination: From Nineveh to Persepolis
}

\author{
Astrid Nunn
}

\section{RÉFÉRENCE}

Margaret Cool Root. « Elam in the Imperial Imagination: From Nineveh to Persepolis », in : Javier Álvarez-Mon, Mark B. Garrison, eds., Elam and Persia. Winona Lake,

Eisenbrauns, 2011, p. 419-474.

1 Parmi les nombreux traits culturels de la civilisation achéménide, on compte la langue, la tradition écrite administrative, l'architecture et l'iconographie. L'A. passe en revue les reliefs de Persépolis pour résumer ce qui y est élamite : vêtement, allégorie du lion, armes et manière de représenter la richesse. D'autres images typiquement élamites comme celles du serpent et de l'eau au contraire manquent. Les Élamites sur ces reliefs sont bien évidemment vus par des lunettes achéménides. Mais il ressort du survey de M. Cool Root que l'Elam était considéré comme une puissance conquérante et absorbante, en aucun cas vulnérable.

\section{AUTEURS}

\section{ASTRID NUNN}

Université de Munich 